\title{
BACTERIAL TRANSLOCATION: MICROBIOTA-INTESTINE-LUNG AXIS AND PRO-INFLAMMATORY STATUS IN THE SEVERITY OF COVID-19
}

\author{
Nereida Valero-Cedeño ${ }^{1 * *(D)}$, Danna Álava ${ }^{1}$, Ronny Rodríguez ${ }^{1}$, Maricarmen Chacín ${ }^{2}$, \\ Maritza Cabrera-Hernández ${ }^{3}$, Teresa Véliz-Castro ${ }^{1}$, Yenddy Carrero ${ }^{4}$ (D), Valmore Bermúdez ${ }^{2}$ (D), \\ Alfonso J. Rodriguez-Morales ${ }^{5, *(\mathbb{D}) \text {, Manish Dhawan }}{ }^{6,7}$ (D), Ruchi Tiwari ${ }^{8}$ (D), Kuldeep Dhama ${ }^{9}$ (iD) \\ ${ }^{1}$ Carrera de Laboratorio Clínico, Facultad de Ciencias de la Salud, Universidad Estatal del Sur de Manabí, Jipijapa, Ecuador \\ ${ }^{2}$ Universidad Simón Bolívar, Facultad de Ciencias de la Salud, Barranquilla, Colombia \\ ${ }^{3}$ Centro de Investigación de Estudios Avanzados del Maule (CIEAM), Vicerrectoría de Investigación y Postgrado, Universidad Católica del Maule, Chile \\ ${ }^{4}$ Carrera de Medicina, Facultad de Ciencias de la Salud, Universidad Técnica de Ambato, Ambato, Ecuador \\ ${ }^{5}$ Grupo de Investigación Biomedicina, Faculty of Medicine, Fundación Universitaria Autónoma de las Américas, Pereira, Colombia \\ ${ }^{6}$ Department of Microbiology, Punjab Agricultural University, Ludhiana-141004, India \\ ${ }^{7}$ The Trafford Group of Colleges, Manchester-WA14 5PQ, United Kingdom \\ ${ }^{8}$ Department of Veterinary Microbiology and Immunology, College of Veterinary Sciences, Uttar Pradesh Pandit Deen Dayal Upadhyaya Pashu Chikitsa Vigyan \\ Vishwavidyalaya Evam Go Anusandhan Sansthan (DUVASU), Mathura-281 001, India \\ ${ }^{9}$ Division of Pathology, ICAR-Indian Veterinary Research Institute, Bareilly, Izatnagar, Uttar Pradesh-243122, India \\ Received - April 29, 2021; Revision - June 01, 2021; Accepted - June 15, 2021 \\ Available Online - June 25, 2021
}

DOI: http://dx.doi.org/10.18006/2021.9(3).239.253

\section{KEYWORDS \\ COVID-19 \\ SARS-CoV-2 \\ Microbiota \\ Microbiome \\ Bacterial translocation}

\begin{abstract}
Although severe acute respiratory syndrome coronavirus - 2 (SARS-CoV-2), causing coronavirus disease 2019 (COVID-19) pandemic, is primarily associated with a respiratory infection, it has also been linked to multisystem involvement that includes the digestive tract. Gastrointestinal (GI) manifestations are common in patients with COVID-19 due to the high viral load lodged in the small intestine's mucosa. As a result, it causes an increase in the permeability of the intestinal barrier that favours the passage and translocation of bacteria, from the lumen of the intestine, towards the internal environment, with the appearance of sepsis, with evidence that SARS-CoV-2 has been found in faeces. This article highlights epidemiology, clinical symptoms, and mechanisms related to manifestations of disease in the GI tract and its pathogenesis in patients with COVID-19. It highlights bacterial translocation and COVID19 , mechanisms that control bacterial translocation, intestinal infection and feco-oral transmission, defense
\end{abstract}

* Corresponding author

E-mail: nereida.valero@unesum.edu.ec (Nereida Valero-Cedeño), alfonso.rodriguez@uam.edu.co (Alfonso J. Rodriguez-Morales), kdhama@rediffmail.com (Kuldeep Dhama)

Peer review under responsibility of Journal of Experimental Biology and Agricultural Sciences.

Production and Hosting by Horizon Publisher India [HPI] (http://www.horizonpublisherindia.in/).

All rights reserved.
All the articles published by Journal of Experimental Biology and Agricultural Sciences are licensed under a Creative Commons Attribution-NonCommercial 4.0 International License Based on a work at www.jebas.org.

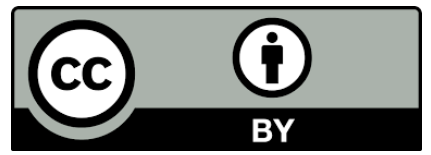


Gastrointestinal tract

Immunomodulation

mechanisms against microbial invasion, role of microbiota/microbiome and implications of their dysbiosis and alterations during SARS-CoV-2 infection, and lastly protective health benefits by improving dietary habits with nutritional foods approaches amid the ongoing pandemic. Increasing evidence indicates that bacterial translocation appears due to the high viral load of COVID-19 in the mucosa of the GI tract, and the intestinal microbiota contributes to the COVID-19 course owing to their bidirectional relationship with the immune system and lungs. Dysbiosis in gut microbiota leads to increased gut permeability thus predisposing to secondary infection and multiple organ dysfunction. Disruption of intestinal barrier integrity due to dysbiosis may cause translocation of SARS-CoV-2 from lungs into the intestinal lumen via the circulatory and lymphatic system, initiating severe clinical presentation of the infection. A thorough understanding of the key role of gut microbiota, gastrointestinal symptoms, and pathology along with immunomodulatory approaches would help in alleviating morbidity and mortality during the ongoing COVID-19 pandemic.

\section{Introduction}

Coronaviruses (CoVs) are a large family of viruses that can trigger a vast range of health conditions, including common cold, more severe illnesses, such as the Middle East respiratory syndrome coronavirus (MERS-CoV) and the severe acute respiratory syndrome (SARS-CoV), and the recently emerged SARS-CoV-2 that is causing coronavirus disease 2019 (COVID-19) pandemic (Dhama et al., 2020a; WHO, 2020a; Rabaan et al., 2021a). SARS$\mathrm{CoV}-2$, a member of the genus Betacoronavirus, is formally named by the World Health Organization (WHO) because it is genetically related to SARS-CoV that caused the 2003 SARS outbreak (WHO, 2020b). In March 2020, the COVID-19 global pandemic was declared a public health emergency of international concern, and thereafter affecting the lives of billions of people worldwide and resulting in more than 172 million infected cases and more than 3.7 million deaths as of June 5, 2021 (Nishiga et al., 2020; WHO, 2021). It is associated with a continuous outbreak of typical pneumonia and other specific clinical presentations, affecting the inhabitants of almost all countries or regions of the world (Dhama et al., 2020b; Lu et al., 2020; Walls et al., 2020; WHO, 2021). This has led to being declared a global health emergency with high virulence factors (Valero et al., 2020).

Infections of CoVs, possess a unique characteristic that is closely related to the biology of virus and characteristics of the host. Typical clinical presentations range from mild upper respiratory distress to severe atypical pneumonia due to upper respiratory tract infection and the presence of dry cough. In addition, the highest risk has been established during the interaction between patient's contacts, and a slight disproportion of respiratory symptoms are observed if compared with radiographic findings (Valero et al., 2005).

Furthermore, the novel coronavirus SARS-CoV-2 uses its spike glycoprotein (S-glycoprotein) to activate the angiotensinconverting enzyme 2 (ACE2), responsible for undertaking cellular protection and cooperating with cellular serine protease
(TMPRSS2) on the cell surface, which facilitates the entry and spread of the virus (Lucas et al., 2014; Dhama et al., 2020a; Dhama et al., 2020b). The most significant observation was that the ACE2 protein is highly expressed in type II alveolar epithelial cells, which are located in the smooth muscle and endothellium of various human organs such as the lung, stomach, small intestine, colon, liver, kidneys, and digestive tract (Hamming et al., 2004); as a result, respiratory and gastrointestinal (GI) manifestations are most common in patients (Derosa et al., 2020). Earlier studies revealed a high prevalence of enteric symptoms in COVID-19 patients, which has also shown acute viral replication in the mucosa of the small intestine. Likewise, fecal shedding of SARS$\mathrm{CoV}$ was found in patients in the first few days of viral infection. SARS-CoV-2 was later discovered to bind to ACE2 receptors in intestinal and respiratory tracts, this being an entrance point of the virus into epithelial cells (Wan et al., 2020).

Intestinal dysfunction has been related, in part, to a decrease in immune competence and a loss of anatomical and functional integrity of the gastrointestinal tract (Belkaid \& Hand, 2014). As a result, the growth in permeability within the intestinal barrier (IB), allows bacterial translocation (BT)per gram of content of bacteria, from the lumen of the intestine to the internal extraintestinal environment. The key component of the intestinal mucosal barrier is the intestinal epithelium, which is specifically bacterial infection in the bloodstream, due to the appearance of endogenous bacteremia especially in the lung and bacterial sepsis due to absorption of endotoxins and other bacterial products and remote infections (Farré et al., 2020). The GI tract is colonized by a range of microorganisms, which are called the intestinal microbiome. Although the intestine provides a functional barrier between pathogen organisms and the host, bacterial translocation is not an uncommon event in healthy people. However, in critical patients, who are carriers of different nosological entities, bacterial translocation is an ideal condition for infections, which consequently cause morbidity and mortality (Acosta \& Rodríguez, 2007). 
Bacterial translocation consists of the passage of viable bacteria from GI tract to different sites in the body outside of it, causing in most cases disruption of the integrity of the intestinal mucosa, such as the mesenteric lymph nodes, bloodstream, as-cites fluid, or causing damage to the pancreas (Berg, 1995). In the clinical field, there has been a growing interest in this phenomenon, due to the many clinical implications, which are still unknown but have progressively been attributed to it (Soriano \& Guarner, 2003). Microbiota aids in establishing protective immune responses against respiratory pathogens via a bidirectional cross-talk ("gutlung axis). The intestinal microbiota also plays a primary function in modulating the host's immune system, and comprises the community of microorganisms that inhabit the intestine; and serves two main functions of digestive and protective capacities with antiviral immune response mechanisms (Belkaid \& Hand, 2014; Scarpellini et al., 2015; Marchesi et al., 2016; Ahmadi Badi et al., 2021; Gasmi et al., 2021). Any anomaly and alterations, within the intestinal microbiota, carries with it, the risk of autoimmune diseases such as asthma, celiac disease, or inflammatory bowel disease and chronic diseases including type II diabetes mellitus (DM2), obesity, or any other metabolic syndromes as well as other implications have been documented (Marchesi et al., 2016; Barriga et al., 2020; Dhar \& Mohanty, 2020; Gu et al., 2020; Ahmadi Badi et al., 2021).

Because microbial dysbiosis has been identified in several patients of COVID-19, prebiotics or probiotics usage (in the form of food supplements or a variety of microorganisms) might prevent secondary infection caused by bacterial translocation (WHO, 2020c; Baud et al., 2020; Ahmadi Badi et al., 2021). Probiotics are beneficial live bacteria and fungi microorganisms, that can be orally administered to the patients, which are helpful in the prevention and treatment of various diseases and disorders including infectious diseases, also allowing the reduction of incidence and severity of viral respiratory tract infections including SARS-CoV-2 (Dhama et al., 2017; Campanella et al., 2018; Sanders et al., 2019; Baud et al., 2020; Infusino et al., 2020; Sundararaman et al., 2020; Kurian et al., 2021). Chinese studies, report clinical evidence in SARS indicating that SARS-CoV, may have a tropism for the GI tract, causing dysbiosis, which may alter subsequent immune function and predispose the host to secondary bacterial infection in the host. Those findings have relevant implications in the current pandemic because alternative preventive strategies including applications of probiotics are urgently needed to flatten the COVID-19 curve worldwide (Baud et al., 2020; Lee \& Paik, 2021). It is also accepted that gastrointestinal function is especially influenced by stress, and under such circumstances, there is a risk of bacterial overgrowth and consequently a progressive bacterial translocation (Ortiz-Prado et al., 2020; Xie \& Chen, 2020).
Likewise, it has been noted that patients with COVID-19 have shown microbial dysbiosis in the intestine, with a reduction of probiotics like Lactobacillus and Bifidobacterium (Dhar \& Mohanty, 2020; Gu et al., 2020; Saleh et al., 2020). Many clinical investigations of COVID-19 individuals have found that gastrointestinal problems tend to occur before or after respiratory symptoms (Trottein \& Sokol, 2020). Furthermore, new research has discovered tentative evidence that the unbalanced gut flora in recovered patients may not be totally repaired, underscoring the significance of ongoing gut health monitoring in persons who have recovered with COVID-19 (Tian et al., 2021). In this respect, an urgent assessment of nutritional and gastrointestinal function in patients with COVID-19 manifestations has been recommended. Apart from the nutritional support, there is evidence to support the administration of probiotics for regulating the balance of intestinal microbiota to alleviate risks of secondary infection via bacterial translocation (Xu et al., 2020a; Baud et al., 2020; Infusino et al., 2020; Sundararaman et al., 2020; Gasmi et al., 2021; Kurian et al., 2021; Lee \& Paik, 2021).

The purpose of this literature review is to gain an understanding of the existing research of the growing number of reported cases of COVID-19, and examine relevant topics in the field of epidemiology, clinical symptoms, and mechanism of action, related to manifestations within the GI tract, that could lead to bacterial translocation and infections in patients with SARS-CoV-2; aimed to reduce the risk of transmission of SARS-CoV-2 worldwide.

\section{Epidemiology}

COVID-19 was first reported in China (December 2019) and to date, it has spread to more than two hundred countries (Walls et al., 2020; Lu et al., 2020; WHO, 2020e; ECDC, 2020; WHO, 2021). At the time of writing, the United States of America reported the largest number of cases 33.2 million, followed by India and Brazil with 27.89 and 16.47 million cases, respectively (WHO, 2021). The conclusions of Paltiel et al. (2021) show that health officials urgently need to invest more funding and attention in vaccine manufacturing and distribution programmes; to increase efforts to foster public trust in COVID-19 vaccines and to promote continued compliance with other mitigating approaches, even once a vaccine is accessible.

Between, December 30, 2019, and June 5, 2021, more than 172 million cases and over 3.7 million deaths have been recorded globally (Nishiga et al., 2020; WHO, 2021). Around half of these cases $48 \%$ and deaths $55 \%$ have been recorded from the Region of the Americas; with the United States of America, Brazil, and Argentina being the countries having the highest number of new COVID-19 cases and deaths in the region. Southeast Africa has reported $12 \%$ of all deaths worldwide. 


\section{Clinical symptoms}

The novel COVID-19 disease caused by coronavirus has produced symptomatic infection ranging in severity from mild to critical (Dhama et al., 2020b). A study conducted in the United State revealed the seriousness of the disease by analyzing 2741 patients hospitalized in New York and having $24 \%$ deaths. This study demonstrated that the fatality rate of COVID-19 is higher as compared to influenza. Even though the severity of the disease varies across location, most of the fatalities worldwide have occurred in patients of advanced age or with underlying medical comorbidities such as cardiovascular disease (CVD), diabetes mellitus, hypertension, chronic lung disease, cancer, chronic kidney disease, obesity or smoking, in conjunction to delayed care, overburdened health care systems, and affected by social determinants of health (Arumugam et al., 2020) Initial symptoms include pneumonia as the most frequent manifestation, characterized by fever and dry cough. In addition, upper respiratory tract symptoms, myalgia, diarrhea, and smell or taste disorders are also commonly seen (Alshukry et al., 2020).

However acute respiratory distress syndrome (ARDS), cardiovascular complications, pulmonary acute stroke, and neurological response, are some of the most serious symptoms that appear with the SARS-CoV-2 infection affecting multiple organs (Dhama et al., 2020a; Chen et al., 2021; Thakur et al., 2021). Inflammatory complications can persist in patients with severe COVID-19, including elevated pro-inflammatory cytokine level (Alshukry et al., 2020; Gulati et al., 2020), together with prothrombotic immunopathology and intense lymphopenia, culminating in multiorgan failure and death (Lozada \& Núñez, 2020; Rabaan et al., 2021b; Rabaan et al., 2021c).

Asymptomatic carriers have also been described who experience non-specific gastrointestinal symptoms (eg, nausea and diarrhea). Various reports have defined gastrointestinal symptoms in COVID-19 patients (Guo et al., 2021; Jin et al., 2021). According to the study, the pooled prevalence of these symptoms was reported in 18 percent of the cases and abdominal distress in more than 10 percent of cases. Histopathology of lungs reveals diffuse alveolar damage with isolated alveolar lining cells and interstitial fibrosis. Evidence of an increased incidence of thromboembolism in COVID-19 patients and elevated inflammatory markers of Creactive protein (CRP), ferritin, and inflammatory cytokines as well as elevated D-dimer ( $>1 \mathrm{mcg} / \mathrm{mL})$ is recorded amongst the laboratory abnormalities detected (ECDC, 2020; Alshukry et al., 2020).

Similarly, patients with COVID-19 have lower T-cell counts and other associated clinical markers of inflammation (ferritin and Creactive protein), while high concentrations of plasmablasts get associated with more severe disease (Van Leeuwen et al., 1994;
Rabaan et al., 2021b). Even though findings from earlier SARS$\mathrm{CoV}$ and MERS-CoV outbreaks have been used by the medical community to predict features of this pandemic along with clinical manifestations, and also potential treatments for COVID-19 (Gulati et al., 2020); many differences still need to be confronted.

The genome of $\mathrm{CoV}$ contains six major reading frames and many genes. Amongst them, the first reading frames encode two large strains of proteins called polyprotein 1a (pp1a) and pp1ab, being the main function of the viral RNA replication (Tufan et al., 2020). The remaining genome encodes major proteins comprising spike (S), envelope (E), membrane (M), and nucleocapsid (N) proteins crucial for viral spreading. The SARS- CoV, E protein, for example, is associated with the inflammatory level of interleukin (IL)-1 $\beta$, IL-6, tumor necrosis factor (TNF), which are accountable for the spread of ARDS. On the other hand, the protein $\mathrm{S}$ is located on the surface of CoVs, serves as the receptor responsible for attachment to host cells, and the infection of the virus into the cell, which is coupled with TNF- $\alpha$ production. Excessive inflammatory response as a consequence of cytokine storms, leading to high levels of mortality, with evidence of the implication of the IL- 6 and C-reactive protein, considerably associated with patients who have died (Ortiz-Prado et al., 2020; Tufan et al., 2020; Rabaan et al., 2021c).

\section{Mechanism of action}

Viral entry proceeds with the interaction of the viral particle with specific proteins on the cell surface. The glycoprotein on that surface of the $\mathrm{CoV}$ plays a crucial role in binding to the receptor. After the initial contact, enveloped viruses must fuse their envelope with the host cell membrane to transport their nucleocapsid to the target cell. Spike proteins assemble on the virion surface to form the distinctive "corona", or crown-like appearance. The spike protein (S-protein)SARS-CoV-2 is reported to bind to the ACE2, the same receptor as SARS-CoV to attack host cells (Belouzard et al., 2012; Dhama et al., 2020a; Ou et al., 2020).

The coronavirus $\mathrm{S}$ protein is comprised of 2 functional subunits: S1 subunit, where receptor-binding domain (RBD) is positioned that facilitates binding of host cell surface receptors; and S2 subunit, which mediates subsequent fusion between viral and host cell membranes (Ortiz-Prado et al., 2020). It might explain the high development and rapid spread from the person-to-person transmission of COVID-19. Some studies have revealed positive stool and rectal swab samples from infected patients of COVID-19, indicating a possible route of faecal-oral transmission (Xie \& Chen, 2020; Cuicchi et al., 2021; Guo et al., 2021).

\section{Bacterial translocation}

The GI tract, besides being the organ responsible for the absorption of nutrients, is also important to the metabolic and immune system 
and provides an effective barrier mechanism against the endotoxin and bacterial microorganisms in the intestinal lumen (Mathew et al., 2020). The passage of bacteria through the gastrointestinal mucosa to the circulatory system or the lymphatic system is called a bacterial translocation (Runyon et al., 1994). This mainly occurs when the physiological mechanisms of protection against translocation are interrupted by a decrease in the blood flow, due to the mesentery or alteration in the structure and function of the intestine. A variety of causes are associated with such alteration in the patient's immune response. These can be identified as hemorrhagic shock, burns, polytraumatism, hepatic insufficiency, malnutrition, cirrhosis, parenteral nutrition, portal hypertension, critical patients, intestinal obstruction and obstructive jaundice, being more serious in critical patients; acute pancreatitis, endotoxemia, intestinal obstruction, and immunosuppressed patients among others (Soriano \& Guarner, 2003).

However, the more predictable consequence of bacterial translocation is the development of infections. As a result, bacterial translocation in patients with COVID-19 must be a factor to consider in treatment and intervention. In a study conducted by O'Boyle et al. (1998), 448 surgical patients underwent laparotomy for various reasons, and the bacterial translocation incidence, and its association with the development of bacterial infections was analyzed. The incidence of bacterial translocation was found to be $15.4 \%$ with patients aged over 70 years old, being the most significant predictor of translocation; in addition, $41 \%$ of the patients were found to have bacterial translocation, then developed bacterial infections in the postoperative period; in contrast to $19 \%$ who did not show bacterial translocations.

Bacterial translocation is not only related to the development of various infections both experimental and clinical; but is also implicated in other processes such as multi-organ failure and the current presence of COVID-19 (El-EbiaryAlarcón, 1994). In this context, another study performed by Zhang et al. (2020), based on a simple of 15 COVID-19 patients, pointed out a permanent alteration in the fecal microbiome in a period of hospitalization of these patients. Fecal microbial alterations were linked to fecal SARS-CoV-2 levels and severity of COVID-19, suggesting that strategies that lead to alteration of intestinal microbiota, could contribute to reducing the severity of the disease.

In addition, the intestinal bacterial translocation might participate in a supplementary/synergistic function in cytokine release syndrome during SARS-CoV-2 infection. There is evidence of the involvement of the intestinal-liver axis, and gut-lung axis as along with support for the hypothesis that intestinal endothelitis and permeability changes with bacterial translocation are critical pathophysiological events in modulating systemic inflammatory response (Ciornei, 2020; Cardinale et al., 2020; Ahmadi Badi et al., 2021; Yang et al., 2021).

\subsection{Pathogenesis of bacterial translocation}

The appearance of bacterial translocation implies a failure in the barrier protection provided by the intestinal tract, against the intestinal lumen or microbiome itself (Berg, 1995). Three main mechanisms are activated in the ideal development of bacterial translocation. Firstly, an alteration in the normal state of the bacterial ecological balance occurs within the intestinal microbiome, more specifically an overgrowth of Gram-negative aerobic bacilli (Teo et al., 2013). Secondly, the dysfunction of the host's immune defense mechanisms (Solà \& Soriano, 2002) and finally, an alteration in the intestinal barrier, causing augmentation of intestinal permeability for bacteria growth. Activation of all these factors is responsible for bacterial translocation (Corradi et al., 2012).

Consequently, the intestinal bacterial overgrowth triggers a very vital role in the pathogenesis of bacterial translocation, being favoured by alterations in local immune defense mechanisms, a decrease in the intestinal motility, and the prolonged administration of antibiotics (Acevedo, 2015).

\subsection{Mechanisms that control bacterial translocation}

The mechanism for controlling bacterial translocation depends on microbial factors and the patient's response, so facultative intracellular pathogens such as Salmonella might translocate easily, whilst anaerobic bacteria rarely do. Steffen et al. (1988) compared relative capacities of facultative aerobe and anaerobe bacteria to translocate from GI tract to the mesenteric lymph nodes (MNL). The biological study utilized gnotobiotic mice colonized with individual bacterial strains and enteric gram-negative bacilli (GNB), were found largely translocated to GLM, while Grampositive bacteria were translocated at intermediate levels and obligate anaerobic bacteria at only very low levels. Findings of this study recommend that enteric bacilli like Escherichia coli, Proteus, and Enterobacter are highly linked with incidences of bacteremia in patients affected with diseases such as COVID-19, or other diseases that debilitate the immune system.

\section{Defense mechanisms against microbial invasion}

Host defenses against intestinal microbial invasion and many conditions that increase in prevalence with age, include numerous mechanisms such as interactions of gut microbiota/microbiome with innate and adaptive immune systems in maintaining intestinal homeostasis, pancreatic enzymes, bile, mucus layer, gastric acid, epithelial cell barrier with its intercellular junctions, peristalsis and the local immune system specific antigen ( $\operatorname{IgA})$ which plays a role in the inhibition of inflammatory effects and also is excreted with bile, known as lymphoid tissue associated with the intestine (Yoo et al., 2020; Narasimhan et al., 2021). Several host cells, such as 
macrophages, enterocytes, and $\mathrm{T}$ lymphocytes, also play an important role as modulators of bacterial translocation in which the defense mechanisms or bacterial virulence are altered or modified. They also indicated multiple alterations in the mechanisms of immune defense, at the systemic level, in which bacterial translocation might occur. As a result, a decrease in the activity of the reticuloendothelial system occurs, along with dysfunction of phagocytic activity of the neutrophils and a decrease in the concentration of several serum proteins with opsonin activity (Zhang \& Dong, 2020).

\section{Bacterial translocation and COVID-19}

The great concerns with SARS-CoV infection are the "silent" or asymptomatic carriers, because of the loss of control, due to its relentless transmissibility, and specifically, because these individuals do not show respiratory symptoms or fever, so they do not know they are infected. Scientific evidence demonstrates that multiple manifestations including gastrointestinal symptoms, bacterial and fungal coinfection in patients of SARS-CoV-2 infection require antimicrobial prescribing apart from recommended treatment protocols, which can play a key role in checking COVID-19 (Pelletier et al., 1982; Rawson et al., 2020). D'Amico et al. (2020), proposed a model for SARS-CoV-2-linked diarrhea. They showed that patients affected with COVID-19 have an incidence rate of diarrhea which varies from $2 \%-50 \%$ of the cases. The authors also observed that such symptoms can precede the subsequent respiratory manifestations. This pooled analysis showed an overall occurrence rate of diarrhea as $10.4 \%$, and also indicated that SARS-CoV-2 utilizes ACE2 receptor and serine protease TMPRSS2 for priming the S-protein. ACE2 and TMPRSS2 are expressed in the lung as well as in the small bowel epithelium. ACE2 is also expressed in the upper esophagus, liver, and colon. The binding affinity of SARS-CoV-2 to ACE2 is potentially higher (10-20 times) than from SARS-CoV. Many pieces of evidence have revealed the release of viral RNA in feces to be detectable for a longer period than in nasopharyngeal swabs (Gupta et al., 2020; Walsh et al., 2020; Yuan et al., 2021; Zhang et al., 2021). According to recent pieces of evidence, it has been suggested that the gut microbiota appears to be eventually able to increase the host's response to respiratory viral infections. Microbiota dysbiosis, ironically, can aggravate the disease's prognosis. The involvement of the gut microbiota in hCoVs infection is unknown (Trottein \& Sokol, 2020; Haiminen et al., 2021). ACE2 receptor expression in GI epithelial cells was discovered in a recent study. This shows that SARS-CoV-2 can infiltrate and propagate in the gastrointestinal system (Wong et al., 2020), particularly in the ACE2 receptor-rich lining of the lower intestine (Wadman et al., 2020; Li et al., 2020). The new strain binds to humans ACE2 10-20 times more powerful than its relative SARS, according to scientific studies. Owing to the high amount of co-expression of TMPRSS2 and ACE2 in enterocytes, lungs, and oesophagus, several researches have provided more indications that CoVs may invade the digestive tract (Meng et al., 2021).

\subsection{Diffusion of fecal-oral coronavirus}

Apart from common respiratory symptoms, some COVID-19 patients also have gastrointestinal symptoms, that were not previously considered indicative of that infection (D'Amico, et al., 2020; Zhong et al., 2020; Cuicchi et al., 2021; Guo et al., 2021; Jin et al., 2021; Yusuf et al., 2021). The most common GI symptoms during COVID-19 are lack of appetite, nausea, and vomiting (Pan et al., 2020). According to a recent review by Zhong et al. (2020), a study performed in the USA reported $61.3 \%$ of patients with at least one GI symptom, $34 \%$ with a loss of appetite, $33.7 \%$ with diarrhea, and $26.4 \%$ with nausea. These symptoms might cause intestinal dysfunction, changes in the bacterial microbiome, and acute systemic inflammation amongst other pathologies (Pan et al., 2020). Some other studies also support these findings, for instance, a systematic review through a meta-analysis showed $12 \%$ of COVID-19 patients to have diarrhea (4.3-12.2\%), nausea, and vomiting (2.6-8.0\%). Those authors also discussed a study conducted in China where the rate of diarrhea was $34.0 \%$ (Zhong et al., 2020).

Further, Wölfel et al. (2020) employed an in vitro model comprising of organoid cultures of epithelial lining cells of human small and large intestine to investigate SARS-CoV-2 entrance and replication within enterocytes. Mature enterocytes expressing the highest levels of ACE2 receptor were particularly vulnerable to viral infection. Virus entrance into enterocytes was boosted by two similar membrane-bound serum proteases, TMPRSS2 and TMPRSS4. While a subset of COVID-19 patients eliminates high levels of viral RNA in their faeces, investigation using simulated human colon fluid suggests that the eliminated virus is quickly inactivated during transit through the colon, reducing the risk of virus spread via the fecal-oral route (Wölfel et al., 2020). As per present knowledge of the expression of SARS-CoV-2 receptors at epithelial barrier sites (Zhang et al., 2020), research by Hamming et al. (2004), to understand tissue distribution of ACE2 protein at SARS-CoV-2 receptors, indicates that the GI tract needs particular attention. ACE2 is distributed homogeneously at brush borders of enterocytes through the small intestine and lung epithelium. The basal layer of non-keratinized squamous epithelial cells of oral mucosa was found positive for ACE2, while in the stomach the epithelial cells and enterocytes of the colon appeared negative. TMPRSS2 and TMPRSS4 mediate infection of small intestinal epithelial cells, which could also act as an attractive target for treatment or intervention strategies, as a clinically approved protease inhibitor is available. Not much is recognized about the 
GI distribution of enteric CD147. Since CD147, appears to have a role in carcinogenesis and inflammation, this could throw light on the group of patients who are at risk for severe SARS-CoV-2 infections and therefore require additional explorative attention (Soriano \& Guarner, 2003).

\subsection{Elimination of SARS-Cov-2 RNA in faeces and alterations} in microbiota

The SARS-CoV-2 infection acquired by the fecal-oral mechanism is still not clear, however, many studies affirm about the potential intestinal infection that it is possible to be infected by this route (Cuicchi et al., 2021; Guo et al., 2021). In this context, a study by $\mathrm{Xu}$ et al. (2020b) using 10 SARS-CoV-2 patients in China, none of whom needed respiratory support or intensive care and with no signs of pneumonia, eight patients were tested positive for rectal swabs, even though the nasopharyngeal test was negative on several consecutive occasions. These results put forward that viral RNA in the digestive system is more durable than that in the respiratory tract. GI symptoms and fecal elimination of SARSCoV-2 RNA are often seen in COVID-19 patients that need to receive treatment. However, it is necessary to better understand SARS-CoV-2 replication in the human gut, and prospective fecaloral transmission of this infection (Zang et al., 2020). One recent report of laboratory-confirmed SARS-CoV-2 in the gastrointestinal system has also suggested the virus could infect GI epithelial cells and might be transmitted via the digestive tract implicating the feasibility of fecal-oral transmission (Cuicchi et al., 2021).

Cano et al. (2020) revealed that SARS-CoV-2 has been found in both the reproductive tract and in the mature enterocytes in ACE2, and human steroids situated in the small intestine. The expression of two mucosal specific protease serine (TMPRSS2 and TMPRSS4), increases the fusogenic activity of the SARS-CoV-2 spike and enhances viral entry into host cells, according to these investigators. The simulated human colon fluid also inactivated the viruses discharged in the intestinal lumen, and infectious virus was not isolated in stool samples of patients with COVID-19. The findings obtained emphasize the intestine as a potential organ of replication for SARS-CoV-2, which can facilitate local and systemic disease and the general development of the pandemic disease (Sokolowska et al., 2020). According to some authors the entrance available for the SARS-CoV-2 invasion is through the ACE 2 enzyme receptors, which are mainly expressed in the lungs, but also have been found in the intestines (Hoffmann et al., 2020).

It has been noted that the entry of coronavirus, produces an increase in gut inflammation, causing in turn alterations in the intestinal microbiome. Those manifestations can aggravate the socalled systemic cytokine storm or hyper inflammation in the most critical patients. In this respect, it has been found that most of the co-morbidities of COVID-19 are obesity, hypertension, cardiovascular disease, diabetes, and aging, mostly because these are associated with a decrease in microbial diversity (Munster et al., 2020).

One study by Zuo et al. (2020) with COVID-19 patients in which noteworthy alterations in the fecal microbiomes were comparatively analyzed with the controls, revealed a fortification of opportunistic pathogens and exhaustion of beneficial microorganisms at the time of hospitalization and during the hospitalization period. A relevant finding is that intestinal dysbiosis persisted over time even after the elimination of SARSCoV-2 (deter-mined from throat samples) and the disappearance of respiratory symptoms.

The basal abundance of Coprobacillus, Clostridium ramosum, and Clostridium hathewayi has been correlated with the severity of COVID-19. Additionally, there is an inverse correlation between the abundance of Faecalibacterium prausnitzii (a bacterium that shows an anti-inflammatory effect) and disease severity. In the course of hospitalization, Bacteroides dorei, Bacteroides thetaiotaomicron, Bacteroides massiliensis, and Bacteroides ovatus that negatively regulate ACE2 expression in the gut, were inversely correlated with SARS-CoV-2 load in patient stool samples, resulting in alteration of patients' gut microbes relative to the severity of COVID-19 (Hindson, 2020).

\section{Improving your eating habits, probiotics and prebiotics: Are the solution?}

It is possible to modify the intestinal microbiome by changing the diet and eating habits or by using specific probiotics and prebiotics. Probiotics are living bacteria whose administration is beneficial to health and aid to maintain healthy gut microbiota. They possess several characteristics that determine their potential beneficial effect in the prevention of infections, especially by pathogens of intestinal origin (Dhama et al., 2017; Campanella et al., 2018; Sanders et al., 2019; Baud et al., 2020). There are a large number of probiotics, notably lactobacilli and bifidobacteria, and among their characteristics are resistance in the GI tract to digestive secretions, adhesion to the intestinal epithelium, the safety for use in humans, and the modulation of the intestinal microbiome by inhibiting potentially pathogenic bacteria along with various immunomodulatory and immunostimulatory effects, such as stimulating the production of immune cells, increasing the activity of phagocytic cells or increasing the production of $\operatorname{IgA}$, and recently be beneficial with possessing preventive and therapeutic role against COVID-19 (Dhama et al., 2017; Campanella et al., 2018; Sanders et al., 2019; Baud et al., 2020; Infusino et al., 2020; Sundararaman et al., 2020; Kurian et al., 2021; Ahmadi Badi et al., 2021; Lee \& Paik, 2021). Bifidobacterium and Lactobacillus family bacteria, Clostridium, and others reduce inflammation and have antimicrobial properties 
via various modes of action (Dhama et al., 2017; Iddir et al., 2020). By promoting adequate nutritional status, the immune response can be improved in the early stages of infection. This would depend on dietary fibre intake that decreases the risk of infection. In addition, vitamins $\mathrm{A}, \mathrm{D}, \mathrm{C}$, or $\mathrm{E}$ and omega-3 fatty acids encourage intestinal bacteria to ferment by-products that help the antiinflammatory response (Wang et al., 2020).

Once it is determined which bacteria are associated with the severity of the COVID-19, treatments or diets could be designed to modify them in a matter of days. It may be possible to reduce the inflammatory response by modifying the intestinal microbiome to protect against the more severe consequences of COVID-19. By increasing bacterial diversity, not only does it protect against viral infections, but also other health problems, including mental health (Fu et al., 2020; Ministry of Health, 2020).

\section{Conclusion and Future perspectives}

A better knowledge of the role of intestinal microenvironment, gut microbiota/microbiome, gastrointestinal manifestations, immunopathology, and immunomodulatory approaches would aid in containing and tackling COVID-19 associated morbidity and mortality amidst the ongoing pandemic (Belkaid \& Hand, 2014; Scarpellini et al., 2015; Marchesi et al., 2016; Ahmadi Badi et al., 2021; Gasmi et al., 2021; Rabaan et al., 2021b; Rabaan et al., 2021c). The most predictable consequence of bacterial translocation is its contribution to the development of infections in COVID-19 patients, where microbial factors and the patient's response to treatment play a very important role. The mechanism of action, in which the virus infects the pulmonary alveolar epithelial cells using receptor-mediated endocytosis through ACE2, as an entry receptor, may occur in certain patients because the intestine houses this same enzyme. So the bacterial translocation occurs and causes, in some cases, gastrointestinal symptoms, thus producing an increase in inflammation and alterations in the intestinal microbiome that consequently aggravates the systemic cytokine storm in the most severe patients, increasing morbidity and mortality rates.

Microbiota-intestine-liver-lung axis provides a bidirectional role in the physiopathology of some infectious diseases including COVID-19 (Ahmadi Badi et al., 2021; Yang et al., 2021). During infection by SARS-CoV-1 and SARS-CoV-2, an imbalance of this axis due to intestinal participation and the systemic inflammatory response has been described (Ahmadi Badi et al., 2021; Yang et al., 2021). Likewise, there is evidence that relates the behaviour of the microbiota-intestine-liver axis, the pro-inflammatory state, and the endothelial damage in non-communicable diseases to the COVID-19 severity. Intestinal damage caused by SARS-CoV-2, dysfunction induced by systemic inflammation, and diffuse IL-6mediated vascular damage can enhance intestinal permeability and precipitate bacterial translocation. It has been reported that systemic release of molecular patterns linked with damage by pathogens and activation of immune mechanisms can stimulate patterns of systemic inflammation and tissue damage (Ciornei, 2020; Rabaan et al., 2021b; Rabaan et al., 2021c).

The action of SARS-CoV- 2 on multiple organs and systems of the body, and the tropism of the intestinal epithelium make it a target, which derives a wide range of clinical manifestations and potential feasibility of fecal-oral transmission (Cuicchi et al., 2021; Guo et al., 2021; Jin et al., 2021; Thakur et al., 2021). It is observed that the viral infection itself, the severity of the disease, and the action of certain mechanisms such as inflammation and sepsis, as well as the adverse effects of some drugs, contribute to the appearance of clinical manifestations and alterations of laboratory tests. In addition, given the risk of becoming ill with COVID-19, patients with some chronic diseases of the digestive system have to maintain special therapeutic management to prevent complications (Infante-Velázquez, 2020).

Current studies indicate the likelihood of fecal-oral transmission of SARS-CoV-2, however, there are few studies to determine if bacterial translocation could increase the viral load of COVID-19 in the digestive tract since no research has been conducted with a sufficiently large population. Therefore, it is very important to collect reliable epidemiological information in the shortest possible time, to ensure sufficient preventive measures and better management of the pandemic. Data should be recorded for patients with clear gastrointestinal symptoms either at onset or during the course of illness.

Likewise, it seems feasible to apply feeding protocols or the use of prebiotics and probiotics that favor bacterial translocation in patients with COVID-19, which could help in the immunomodulation of this pathology provided that there are no underlying pathologies that could make its implementation counterproductive (Sanders et al., 2019; Baud et al., 2020; Sundararaman et al., 2020; Kurian et al., 2021; Ahmadi Badi et al., 2021; Lee \& Paik, 2021; Kullar et al., 2021). The nutritional approach should be paid due attention to integral treatment and management for patients with COVID-19. It should be sufficient, complete, balanced, satisfactory, safe and include foods such as fruits, vegetables, legumes, cereals and their derivatives, mainly wholemeal, nuts, and healthy fats, always controlling the quantities; foods of animal origin such as meat, fish, eggs, cheese, dairy products and derivatives; vitamins and mineral supplements, traditional and medicinal herbs, which help in boosting immunity and promote better health (Rahal et al., 2014; Dhama et al., 2018; Alkhatib, 2020; Infusino et al., 2020; Anand et al., 2021; Capodice \& Chubak, 2021; de Faria Coelho-Ravagnaniet al., 2021; Dhawan et al., 2021; Thirumdas et al., 2021), which altogether help in boosting immunity and protect health during the COVID-19 
pandemic. The indicators to monitor include mainly energy and proteins and the maintenance of liquid balance.

\section{Author Contributions}

$\mathrm{NV}, \mathrm{RR}$ and DA, conceived the idea and the general approach of the study. RR, DA, TV, MC, YC, and MCH researched in the literature, wrote and reviewed the manuscript. MC translated the content. VB, AJRM, MD, RT, KD and NV contributed to the review and correction of the manuscript. All authors reviewed and approved the final version of the work.

\section{Funding}

This research received no external funding.

\section{Acknowledgments}

None to declare.

\section{Conflicts of Interest}

The authors declare no conflict of interest.

\section{References}

Acevedo J (2015) Multiresistant bacterial infections in liver cirrhosis: Clinical impact and new empirical antibiotic treatment policies. World Journal of Hepatology 7(7):916. DOI: $10.4254 /$ wjh.v7.i7.916.

Acosta Escribano J, Rodríguez Montes J (2007) Importanciaclínica de la translocaciónbacteriana. Nutrición Hospitalaria 22 (Suppl 2): 50-55. Disponible en: http://scielo.isciii.es/scielo.php?script=sci_ arttext \&pid =S0212-16112007000500007\&lng=es.

Ahmadi Badi S, Tarashi S, Fateh A, Rohani P, Masotti A, Siadat SD (2021) From the role of microbiota in gut-lung axis to SARSCoV-2 pathogenesis. Mediators of Inflammation 2021:6611222.

Alkhatib A (2020) Antiviral functional foods and exercise lifestyle prevention of coronavirus. Nutrients 12: 2633;. doi:10.3390/ nu12092633.

Alshukry A, Ali H, Ali Y, Al-Taweel T, Abu-Farha M, AbuBaker J, Devarajan S, Dashti AA, Bandar A, Taleb H, Al Bader A, Aly NY, Al-Ozairi E, Al-Mulla F, Bu Abbas M (2020) Clinical characteristics of coronavirus disease 2019 (COVID-19) patients in Kuwait. PLoS ONE 15(11): e0242768. Doi: 10.1371/journal.pone.0242768.

Anand AV, Balamuralikrishnan B, Kaviya M, Bharathi K, Parithathvi A, Arun M, Senthilkumar N, Velayuthaprabhu S, Saradhadevi M, Al-Dhabi NA, Arasu MV, Yatoo MI, Tiwari R, Dhama K (2021) Medicinal plants, phytochemicals, and herbs to combat viral pathogens including SARS-CoV-2. Molecules 26(6):1775. DOI: 10.3390/molecules26061775.

Arumugam VA, Thangavelu S, Fathah Z, Ravindran P, Sanjeev AMA, Babu S, Meyyazhagan A, Yatoo MI, Sharun K, Tiwari R, Pandey MK, Sah R, Chandra R, Dhama K (2020) COVID-19, and the world with co-morbidities of heart disease, hypertension, and diabetes. Journal of Pure and Applied Microbiology 14(3):16231638. DOI: 10.22207/JPAM.14.3.01.

Barriga J, Bohórquez N, Bonifaz V, Castillo V, Cazho L, Díaz D, Herrera E, Longo N, Orozco G, Zambrano M (2020) Guía nutricional para Covid-19. Guía nutricional. Quito - Ecuador: OMS, centro clínico quirúrgico Hospital del día el Batán. Available at: https://www.edicionmedica.ec/contenido/images/GUIA\%20COVI D-19\%20\%281\%29.pdf access on $5^{\text {th }}$ May 2021.

Baud D, Dimopoulou Agri V, Gibson GR, Reid G, Giannoni E (2020) Using probiotics to flatten the curve of Coronavirus Disease COVID-2019 pandemic. Frontiers in Public Health 8:186. Doi: 10.3389/fpubh.2020.00186.

Belkaid Y, Hand TW (2014) Role of the microbiota in immunity and inflammation. Cell 157(1):121-41. DOI: 10.1016/j.cell.2014.03.011.

Belouzard S, Millet JK, Licitra BN, Whittaker GR (2012) Mechanisms of corona virus cell entry mediated by the viral spike protein. Viruses 4(6):1011-33. Doi: 10.3390/v4061011.

Berg RD (1995) Bacterial translocation from the gastrointestinal tract. Trends in Microbiology 3(4):149-54. Doi: 10.1016/s0966842x(00)88906-4.

Campanella V, Syed J, Santacroce L, Saini R, Ballini A, Inchingolo F (2018) Oral probiotics influence oral and respiratory tract infections in the pediatric population: a randomized doubleblinded placebo-controlled pilot study. European Review for Medical and Pharmacological Sciences 22(22): 8034-8041. doi:10.26355/eurrev_201811_16433.

Cano F, Gajardo M, Freundlich M (2020) Renin Angiotensin Axis, Angiotensin Converting Enzyme 2 and Coronavirus. Revista Chilena de Pediatría 91(3): 330-338. DOI: http://dx.doi.org/10.32641/rchped.vi91i3.2548.

Capodice JL, Chubak BM (2021) Traditional Chinese herbal medicine-potential therapeutic application for the treatment of COVID-19. Chinese Medicine 16(1):24. DOI: 10.1186/s13020020-00419-6.

Cardinale V, Capurso G, Ianiro G, Gasbarrini A, Arcidiacono PG, Alvaro D (2020) Intestinal permeability changes with bacterial 
translocation as key events modulating systemic host immune response to SARS-CoV-2: A working hypothesis. Digestive and Liver Disease S1590-8658(20)30469-2. DOI: 10.1016/ j.dld.2020.09.009.

Chen X, Laurent S, Onur OA, Kleineberg NN, Fink GR, Schweitzer F, Warnke C (2021) A systematic review of neurological symptoms and complications of COVID-19. The Journal of Neurology 268(2):392-402. DOI: 10.1007/s00415-02010067-3.

Ciornei RT (2020) Prevention of Severe Coronavirus Disease 2019 Outcomes by Reducing Low-Grade Inflammation in High-Risk Categories. Frontiers in Immunology 11:1762. DOI: 10.3389/fimmu.2020.01762.

Corradi F, Brusasco C, Fernández J, Vila J, Ramirez MJ, SevaPereira T, Fernández-Varo G, Mosbah IB, Acevedo J, Silva A, Rocco PR, Pelosi P, Gines P, Navasa M (2012) Effects of pentoxifylline on intestinal bacterial overgrowth, bacterial translocation and spontaneous bacterial peritonitis in cirrhotic rats with ascites. Digestive and Liver Disease 44(3):239-244. Doi: 10.1016/j.dld.2011.10.014

Cuicchi D, Lazzarotto T, Poggioli G (2021) Fecal-oral transmission of SARS-CoV-2: review of laboratory-confirmed virus in gastrointestinal system. International Journal of Colorectal Disease 36(3):437-444. DOI: 10.1007/s00384-020-03785-7.

D'Amico F, Baumgart DC, Danese S, Peyrin-Biroulet L (2020) Diarrhea During COVID-19 Infection: Pathogenesis, Epidemiology, Prevention, and Management. Clinical Gastroenterology and Hepatology 18(8):1663-1672. DOI: 10.1016/j.cgh.2020.04.001.

de Faria Coelho-Ravagnani C, Corgosinho FC, Sanches FFZ, Prado CMM, Laviano A, Mota JF (2021) Dietary recommendations during the COVID-19 pandemic. Nutrition Reviews 79(4):382-393. DOI: 10.1093/nutrit/nuaa067.

Derosa L, Melenotte C, Griscelli F, Gachot B, Marabelle A, Kroemer G, Zitvogel L (2020) The immuno-oncological challenge of COVID-19. Nature Cancer 1:946-964 https://doi.org/10.1038/ s43018-020-00122-3.

Dhama K, Karthik K, Khandia R, Munjal A, Tiwari R, Rana R, Khurana SK, Sana Ullah, Khan RU, Alagawany M, Farag MR, Dadar M, Joshi SK (2018) Medicinal and therapeutic potential of herbs and plant metabolites/extracts countering viral pathogens Current knowledge and future prospects. Current Drug Metabolism 19(3):236-263. DOI: 10.2174/1389200219666180129145252.

Dhama K, Khan S, Tiwari R, Sircar S, Bhat S, Malik YS, Singh $\mathrm{KP}$, Chaicumpa W, Bonilla-Aldana DK, Rodriguez-Morales AJ (2020a) Coronavirus Disease 2019-COVID-19. Clinical Microbiology Reviews 33(4): e00028-20.

Dhama K, Latheef SK, Munjal AK, Khandia R, Samad HA, Iqbal HMN, Joshi SK (2017) Probiotics in Curing Allergic and Inflammatory Conditions - Research Progress and Futuristic Vision. Recent Pat Inflamm Allergy Drug Discovery 10(2):105118. DOI: $10.2174 / 1872213 X 10666161226162229$.

Dhama K, Patel SK, Pathak M, Yatoo MI, Tiwari R, Malik YS, Singh R, Sah R, Rabaan AA, Bonilla-Aldana DK, RodriguezMorales AJ (2020b) An update on SARS-CoV-2/COVID-19 with particular reference to its clinical pathology, pathogenesis, immunopathology and mitigation strategies. Travel Medicine and Infectious Disease 37:101755. DOI: 10.1016/j.tmaid.2020.101755.

Dhar D, Mohanty A (2020) Gut microbiota and Covid-19- possible link and implications. Virus Research 285:198018. doi:10.1016/j.virusres.2020.198018.

Dhawan M, Parmar M, Sharun K, Tiwari R, Bilal M, Dhama K (2021) Medicinal and therapeutic potential of withanolides from Withania somnifera against COVID-19. Journal of Applied Pharmaceutical Science 11(04):006-013.

El-Ebiary Alarcón M (1994) Es la traslocación bacteriana un mecanismo etiopatogénico de la neumonía nosocomial adquirida durante la ventilación mecánica? Archivos de Bronconeumología 30(4): 228. DOI: https://doi.org/10.1016/S0300-2896(15)31101-7

European Centre for Disease Prevention and Control (2020) Covid-19 situation update worldwide, as of 31 october 2020, European centre for disease prevention and control (ECDC). Avalilable at https://www.ecdc.europa.eu/en/geographicaldistribution- 2019-ncov-cases access on 29th April 2021.

Farré R, Fiorani M, Abdu Rahiman S, Matteoli G (2020) Intestinal Permeability, Inflammation and the Role of Nutrients. Nutrients 12(4):1185. DOI: 10.3390/nu12041185.

Fu Y, Cheng Y, Wu Y (2020) Understanding SARS-CoV-2Mediated Inflammatory Responses: From Mechanisms to Potential Therapeutic Tools. Virologica Sinica 35(3):266-271. DOI:10.1007/s12250-020-00207-4.

Gasmi A, Tippairote T, Mujawdiya PK, Peana M, Menzel A, Dadar M, Benahmed AG, Bjørklund G (2021) The microbiota-mediated dietary and nutritional interventions for COVID-19. Clinical Immunology 226:108725. DOI: 10.1016/j.clim.2021.108725.

Gu S, Chen Y, Wu Z, Chen Y, Gao H, Lv L, Li L (2020) Alterations of the Gut Microbiota in Patients with COVID-19 or 
H1N1 Influenza. Clinical Infectious Diseases 71(10):2669-2678. doi:10.1093/cid/ciaa709.

Gulati A, Pomeranz C, Qamar Z, Thomas S, Frisch D, George G, Summer R, DeSimone J, Sundaram B (2020) A comprehensive review of manifestations of novel Coronaviruses in the context of deadly COVID-19 global pandemic. American Journal of the Medical Sciences 360(1):5-34. doi: 10.1016/j.amjms.2020.05.006.

Guo M, Tao W, Flavell RA, Zhu S (2021) Potential intestinal infection and faecal-oral transmission of SARS-CoV-2. Nature Reviews Gastroenterology \& Hepatology 18(4):269-283. doi: 10.1038/s41575-021-00416-6.

Gupta S, Parker J, Smits S, Underwood J, Dolwani S (2020) Persistent viral shedding of SARS-CoV-2 in faeces - a rapid review. Colorectal Disease 22(6):611-620. DOI: 10.1111/codi.15138.

Haiminen N, Utro F, Seabolt E, Parida L (2021) Functional profiling of COVID-19 respiratory tract microbiomes. Scientific Reports 11(1):6433. doi: 10.1038/s41598-021-85750-0.

Hamming I, Timens W, Bulthuis ML, Lely AT, Navis GJ, and Van GH (2004) Tissue distribution of ACE2 protein, the functional receptor for SARS coronavirus. A first step in understanding SARS pathogenesis. Journal of Pathology 203:631-637. Doi:10.1002/path.1570

Hindson J (2020) COVID-19: faecal-oral transmission? Nature Reviews Gastroenterology \& Hepatology 17(5):259. DOI: 10.1038/s41575-020-0295-7.

Hoffmann M, Kleine-Weber H, Schroeder S, Krüger N, Herrler T, Erichsen S, Schiergens TS, Herrler G, Wu NH, Nitsche A, Müller MA, Drosten C, Pöhlmann S (2020) SARS-CoV-2 cell entry depends on ACE2 and TMPRSS2 and is blocked by a clinically proven protease inhibitor. Cell 181(2):271-280.e8. DOI: 10.1016/j.cell.2020.02.052.

Iddir M, Brito A, Dingeo G, Fernandez Del Campo SS, Samouda H, La Frano MR, Bohn T (2020) Strengthening the immune system and reducing inflammation and oxidative stress through diet and nutrition: Considerations during the COVID-19 Crisis. Nutrients 12(6):1562. https://doi.org/10.3390/nu12061562.

Infante Velázquez M (2020) Implicaciones de la infección por el nuevo coronavirus SARS-CoV-2 para el sistema digestivo. Arch Cuba gastroenterol 1(2). Disponible en: http://revgastro.sld.cu/ index.php/gast/article/view/38.

Infusino F, Marazzato M, Mancone M, Fedele F, Mastroianni CM, Severino P, d'Ettorre G (2020) Diet supplementation, probiotics, and nutraceuticals in SARS-CoV-2 infection: A scoping review. Nutrients 12(6). DOI:10.3390/nu12061718.

Jin B, Singh R, Ha SE, Zogg H, Park PJ, Ro S (2021) Pathophysiological mechanisms underlying gastrointestinal symptoms in patients with COVID-19. World Journal of Gastroenterology 27(19):2341-2352. DOI: 10.3748/wjg.v27.i19.2341.

Kullar R, Johnson S, McFarland LV, Goldstein EJC (2021) Potential Roles for Probiotics in the Treatment of COVID-19 Patients and Prevention of Complications Associated with Increased Antibiotic Use. Antibiotics (Basel)10(4):408. doi: 10.3390/antibiotics10040408.

Kurian SJ, Unnikrishnan MK, Miraj SS, Bagchi D, Banerjee M, Reddy BS, Rodrigues GS, Manu MK, Saravu K, Mukhopadhyay C, Rao M (2021) Probiotics in prevention and treatment of COVID-19: Current perspective and future prospects. Archives of Medical Research S0188-4409(21)00047-3. DOI: 10.1016/ j.arcmed.2021.03.002.

Lee NK, Paik HD (2021) Prophylactic effects of probiotics on respiratory viruses including COVID-19: a review. Food Science and Biotechnology 24:1-9. doi: 10.1007/s10068-021-00913-z.

Li LY, Wu W, Chen S, Gu JW, Li XL, Song HJ, Du F, Wang G, Zhong CQ, Wang XY, Chen Y, Shah R, Yang HM, Cai Q (2020) Digestive system involvement of novel coronavirus infection: Prevention and control infection from a gastroenterology perspective. Journal of Digestive Diseases 21(4): 199-204. https://doi.org/10.1111/1751-2980.12862

Lozada-Requena I, Núñez Ponce C (2020) COVID-19: respuesta inmune y perspectivas terapéuticas. Revista Peruana de Medicina Experimental y SaludPública 37(2). DOI: https://doi.org/10.17843/ rpmesp.2020.372.5490.

Lu R, Zhao X, Li J, Niu P, Yang B, Wu H, Wang W, Song H, et al. (2020) Genomic characterisation and epidemiology of 2019 novel coronavirus: implications for virus origins and receptor binding. Lancet 395(10224):565-574. DOI:10.1016/S0140-6736(20)30251-8.

Lucas JM, Heinlein C, Kim T, Hernandez SA, Malik MS, True LD, Morrissey C, Corey E, Montgomery B, Mostaghel E, Clegg N, Coleman I, Brown CM, Schneider EL, Craik C, Simon JA, Bedalov A, Nelson PS (2014) The androgen-regulated protease TMPRSS2 activates a proteolytic cascade involving components of the tumor microenvironment and promotes prostate cancer metastasis. Cancer Discovery 4(11):1310-1325. DOI: 10.1158/2159-8290.CD-13-1010.

Marchesi JR, Adams DH, Fava F, Hermes GD, Hirschfield GM, Hold G, Quraishi MN, Kinross J, Smidt H, Tuohy KM, Thomas 
LV, Zoetendal EG, Hart A (2016). The gut microbiota and host health: a new clinical frontier. Gut 65(2): 330-339. doi:10.1136/gutjnl-2015-309990.

Mathew D, Giles JR, Baxter AE, Oldridge DA, Greenplate AR, Wu JE, Alanio C, et al. (2020) Deep immune profiling of COVID19 patients reveals distinct immunotypes with therapeutic implications. Science 369(6508):eabc8511. doi 10.1126/science.abc8511.

Meng X, Lou QY, Yang WY, Chen R, Xu WH, Yang Y, Zhang L, Xu T, Xiang HF (2021) Gordian Knot: Gastrointestinal lesions caused by three highly pathogenic coronaviruses from SARS-CoV and MERS-CoV to SARS-CoV-2. European Journal of Pharmacology 2021 Jan 5;890:173659. doi 10.1016/j.ejphar.2020.173659.

Ministry of Health (MH, Spain) (2020) España. Información científico-técnica. Enfermedad por coronavirus, COVID-19. Centro de Coordinación de Alertas y Emergencias Sanitarias. Disponible

https://www.mscbs.gob.es/profesionales/saludPublica/ccayes/alerta sActual/nCov/documentos/ITCoronavirus.pdf

Munster VJ, Koopmans M, Van Doremalen N, Van Riel D, de Wit E (2020) A Novel Coronavirus emerging in China - Key questions for impact assessment. New England Journal of Medicine 382(8):692-694. DOI: 10.1056/NEJMp2000929.

Narasimhan H, Ren CC, Deshpande S, Sylvia KE (2021) Young at gut-turning back the clock with the gut microbiome. Microorganisms 9(3):555. doi: 10.3390/microorganisms9030555.

Nishiga M, Wang DW, Han Y, Lewis DB, Wu JC (2020) COVID19 and cardiovascular disease: from basic mechanisms to clinical perspectives. Nature Reviews Cardiology 17(9):543-558. doi: 10.1038/s41569-020-0413-9.

O'Boyle CJ, MacFie J, Mitchell CJ, Johnstone D, Sagar PM, Sedman PC (1998) Microbiology of bacterial translocation in humans. Gut 42(1):29-35. DOI: 10.1136/gut.42.1.29.

Ortiz-Prado E, Simbaña-Rivera K, Barreno LG, Rubio-Neira M, Guaman LP, Kyriakidis NC, et al. (2020) Clinical, molecular, and epidemiological characterization of the SARS-CoV-2 virus and the Coronavirus Disease 2019 (COVID-19), a comprehensive literature review. Diagnostic Microbiology and Infectious Disease 98(1): 115094. DOI: https://doi.org/10.1016/j.diagmicrobio.2020.115094

Ou X, Liu Y, Lei X, Li P, Mi D, Ren L, Guo L, Guo R, Chen T, Hu J, Xiang Z, Mu Z, Chen X, Chen J, Hu K, Jin Q, Wang J, Qian Z (2020) Characterization of spike glycoprotein of SARS-CoV-2 on virus entry and its immune cross-reactivity with SARS-CoV.
Nature Communications 11(1):1620. DOI: 10.1038/s41467-02015562-9.

Paltiel AD, Schwartz JL, Zheng A, Walensky RP (2021) Clinical Outcomes of A COVID-19 Vaccine: Implementation Over Efficacy. Health Affairs (Millwood) 40(1):42-52. DOI: 10.1377/hlthaff.2020.02054.

Pan L, Mu M, Yang P, Sun Y, Wang R, Yan J, Li P, Hu B, Wang J, Hu C, Jin Y, Niu X, Ping R, Du Y, Li T, Xu G, Hu Q, Tu L (2020) Clinical Characteristics of COVID-19 Patients with Digestive Symptoms in Hubei, China: A Descriptive, Cross-Sectional, Multicenter Study. American Journal of Gastroenterology 115(5):766-773. Doi: 10.14309/ajg.0000000000000620.

Pelletier G, Briantais MJ, Buffet C, Pillot J, Etienne JP (1982) Serum and intestinal secretory $\operatorname{IgA}$ in alcoholic cirrhosis of the liver. Gut 23(6):475-480. Doi: 10.1136/gut.23.6.475.

Rabaan AA, Al-Ahmed SH, Garout MA, Al-Qaaneh AM, Sule AA, Tirupathi R, Mutair AA, Alhumaid S, Hasan A, Dhawan M, Tiwari R, Sharun K, Mohapatra RK, Mitra S, Emran TB, Bilal M, Singh R, Alyami SA, Moni MA, Dhama K (2021c) Diverse immunological factors influencing pathogenesis in patients with COVID-19: A review on viral dissemination, immunotherapeutic options to counter cytokine storm and inflammatory responses. Pathogens 10:565. https:// doi.org/10.3390/pathogens10050565.

Rabaan AA, Al-Ahmed SH, Muhammad J, Khan A, Sule AA, Tirupathi R, Mutair AA, Alhumaid S, Al-Omari A, Dhawan M, Tiwari R, Sharun K, Mohapatra RK, Mitra S, Bilal M, Alyami SA, Emran TB, Moni MA, Dhama K (2021b) Role of inflammatory cytokines in COVID-19 patients: A review on molecular mechanisms, immune functions, immunopathology and immunomodulatory drugs to counter cytokine storm. Vaccines (Basel) 9(5):436. doi: 10.3390/vaccines9050436.

Rabaan AA, Al-Ahmed SH, Sah R, Alqumber MA, Haque S, Patel SK, Pathak M, Tiwari R, Yatoo MI, Haq AU, Bilal M, Dhama K, Rodriguez-Morales AJ (2021a) MERS-CoV: epidemiology, molecular dynamics, therapeutics, and future challenges. Annals of Clinical Microbiology and Antimicrobials 20(1):8. doi: 10.1186/s12941-020-00414-7.

Rahal A, Mahima, Verma AK, Kumar A, Tiwari R, Kapoor S, Chakraborty S, Dhama K (2014) Phytonutrients and nutraceuticals in vegetables and their multi-dimensional medicinal and health benefits for humans and their companion animals: A review. Journal of Biological Sciences 14(1): 1-19.

Rawson TM, Moore LSP, Zhu N, Ranganathan N, Skolimowska K, Gilchrist M, Satta G, Cooke G, Holmes A (2020) Bacterial and fungal coinfection in individuals with Coronavirus: A rapid review 
to support COVID-19 antimicrobial prescribing. Clinical Infectious Diseases 71(9):2459-2468. Doi: 10.1093/cid/ciaa530.

Runyon BA, Squier S, Borzio M (1994) Translocation of gut bacteria in rats with cirrhosis to mesenteric lymph nodes partially explains the pathogenesis of spontaneous bacterial peritonitis. Journal of Hepatology 21(5):792-6. DOI: 10.1016 / s0168-8278 (94) 80241-6.

Saleh J, Peyssonnaux C, Singh KK, Edeas M (2020) Mitochondria and microbiota dysfunction in COVID-19 pathogenesis. Mitochondrion 54:1-7. doi:10.1016/j.mito.2020.06.008.

Sanders ME, Merenstein DJ, Reid G, Gibson GR, Rastall RA (2019) Author correction: Probiotics and prebiotics in intestinal health and disease: from biology to the clinic. Nature Reviews Gastroenterology \& Hepatology 16(10): 642. doi:10.1038/s41575019-0199-6.

Scarpellini E, Ianiro G, Attili F, Bassanelli C, De Santis A, Gasbarrini A (2015) The human gut microbiota and virome: Potential therapeutic implications. Digestive and Liver Disease 47(12): 1007-1012. doi:10.1016/j.dld.2015.07.008.

Sokolowska M, Lukasik ZM, Agache I, Akdis CA, Akdis D, Akdis M, Barcik W, Brough HA, et al. (2020) Immunology of COVID19: Mechanisms, clinical outcome, diagnostics, and perspectives-A report of the European Academy of Allergy and Clinical Immunology (EAACI). Allergy 75(10):2445-2476. Doi: 10.1111/all.14462.

Solà R, Soriano G (2002) Why do bacteria reach ascitic fluid? European Journal of Gastroenterology \& Hepatology 14(4):351354. Doi: 10.1097/00042737-200204000-00002.

Soriano G, Guarner C (2003) Prevención de la translocación bacteriana mediante probióticos y prebióticos. Gastroenterology \& Hepatology 26 (Supl 1): 23-3.

Steffen EK, Berg RD, Deitch EA (1988) Comparison of translocation rates of various indigenous bacteria from the gastrointestinal tract to the mesenteric lymph node. Journal of Infectious Diseases 157(5):1032-1038. DOI: 10.1093/infdis/157.5.1032.

Sundararaman A, Ray M, Ravindra PV, Halami PM (2020) Role of probiotics to combat viral infections with emphasis on COVID-19. Applied Microbiology and Biotechnology 104(19): 8089-8104. doi:10.1007/s00253-020-10832-4.

Teo S, Walker A, Steer A (2013) Spontaneous bacterial peritonitis as a presenting feature of nephrotic syndrome. Journal of Paediatrics and Child Health 49: 1069-1071. Doi: 10.1111 / jpc.12389.
Thakur V, Ratho RK, Kumar P, Bhatia SK, Bora I, Mohi GK, Saxena SK, Devi M, Yadav D, Mehariya S (2021) Multi-organ involvement in COVID-19: beyond pulmonary manifestations. Journal of Clinical Medicine10(3): 446. https://doi.org/10.3390/ jcm10030446.

Thirumdas R, Kothakota A, Pandiselvam R, Bahrami A, Barba FJ (2021) Role of food nutrients and supplementation in fighting against viral infections and boosting immunity: A review. Trends in Food Science \& Technology 66-77. DOI: 10.1016/j.tifs.2021.01.069

Tian Y, Sun KY, Meng TQ, Ye Z, Guo SM, Li ZM, Xiong CL, Yin Y, Li HG, Zhou LQ (2021) Gut Microbiota May Not Be Fully Restored in Recovered COVID-19 Patients After 3-Month Recovery. Frontiers in nutrition 8: 638825.https://doi.org/10.3389/ fnut.2021.638825

Trottein F, Sokol H (2020) Potential Causes and Consequences of Gastrointestinal Disorders during a SARS-CoV-2 Infection. Cell Reports 32(3):107915. doi: 10.1016/j.celrep.2020.107915.

Tufan A, Güler AA, Matucci-Cerinic M (2020) COVID-19, immune system response, hyperinflammation and repurposing antirheumatic drugs. Turkish Journal of Medical sciences 50(3): $620-632$.

Valero Nereida, Larreal Yraima, Mosquera Jesús, Rincón Enrique (2005) Síndrome Respiratorio Agudo Severo (SRAS): Lecciones y Retos. Journal of Clinical Investigation 46(1):75-95. Disponible en: http://ve.scielo.org/scielo.php?script=sci_arttext\&pid=S053551332005000100009\&lng=es.

Valero-Cedeño NJ, Mina-Ortiz JB, Veliz-Castro TI, MerchánVillafuerte KM, Perozo-Mena AJ (2020) COVID-19: La nueva pandemia con muchas lecciones y nuevos retos. Revisión Narrativa. Kasmera 48(1): e48102042020. DOI: 10.5281/zenodo.3745322.

Van Leeuwen PA, Boermeester MA, Houdijk AP, Ferwerda CC, Cuesta MA, Meyer S, Wesdorp RI (1994) Clinical significance of translocation. Gut 35(1 Suppl): S28-34. Doi: 10.1136/gut.35.1_suppl.s28.

Wadman M, Couzin-Frankel J, Kaiser J, Matacic C (2020) A rampage through the body. Science 368(6489):356-360. doi: 10.1126/science.368.6489.356.

Walls AC, Park YJ, Tortorici MA, Wall A, McGuire AT, Veesler D (2020) Structure, Function, and Antigenicity of the SARS-CoV2 Spike Glycoprotein. Cell 181(2):281-292. e6. DOI: 10.1016/j.cell.2020.02.058. 
Walsh KA, Jordan K, Clyne B, Rohde D, Drummond L, Byrne P, Ahern S, Carty PG, O'Brien KK, O'Murchu E, O'Neill M, Smith SM, Ryan M, Harrington P (2020) SARS-CoV-2 detection, viral load and infectivity over the course of an infection. Journal of Infection 81(3):357-371. DOI: 10.1016/j.jinf.2020.06.067.

Wan Y, Shang J, Graham R, Baric RS, Li F (2020) Receptor recognition by the novel coronavirus from Wuhan: an analysis based on decade-long structural studies of SARS coronavirus. Journal of Virology 94:e00127-20. https://doi .org/10.1128/JVI.00127-20.

Wang W, Xu Y, Gao R, Lu R, Han K, Wu G, Tan W (2020) Detection of SARS-CoV-2 in different types of clinical specimens. JAMA 323(18):1843-1844. doi: 10.1001/jama.2020.3786.

WHO (2021) WHO COVID-19 Dashboard - Up to date data on pandemic. https://covid19.who.int/?gclid=CjwKCAiApNSABhAl EiwANuR9YM0k0JigJ56NivXbxLo_GNuUC2W0j79EBV9ZLho5 WBFDR7AO8Bt2ihoCqfoQAvD_BwE Accessed on June 2, 2021.

Wölfel R, Corman VM, Guggemos W, Seilmaier M, Zange S, Müller MA, Niemeyer D, Jones TC, Vollmar P, Rothe C, Hoelscher M, Bleicker T, Brünink S, Schneider J, Ehmann R, Zwirglmaier K, Drosten C, Wendtner C (2020) Virological assessment of hospitalized patients with COVID-2019. Nature 581(7809):465-469. doi: 10.1038/s41586-020-2196-x. Epub 2020 Apr 1. Erratum in: Nature. 2020 Dec;588(7839):E35.

Wong SH, Lui RN, Sung JJ (2020) Covid-19 and the digestive system. Journal of gastroenterology and hepatology, 35(5): 744748. DOI: https://doi.org/10.1111/jgh.15047.

World Health Organization (2020a) Coronavirus. (Online). Available at: https://www.who.int/es/health-topics/coronavirus/ coronavirus access on 29th April 2021.

World Health Organization (2020b) Los nombres de la enfermedad por coronavirus (COVID-19) y del virus que la causa. (Online) Available at https://www.who.int/es/emergencies/diseases/novelcoronavirus-2019/technical-guidance/naming-the-coronavirus-

disease-(covid-2019)-and-the-virus-that-causes-it access on 27 July 2020 .

World Health Organization (2020c) La administración de suplementos de vitamina A a adultos infectados por el VIH y la progresión de la enfermedad. Available at: https://www.who.int/elena/titles/bbc/vitamina_hiv_adults/es access on 29th April 2021.

World Health Organization (2020d) Brote de enfermedad por el Coronavirus (COVID-19) Available at: https://www.paho.org/es/temas/coronavirus/brote-enfermedad-porcoronavirus-covid-19 access on 29th April 2021.
World Health Organization (2020e) WHO Coronavirus Disease (COVID-19) Dashboard. Available at https://covid19.who.int/ access on 29th April 2021.

Xie M, Chen Q (2020) Insight into 2019 novel coronavirus- An updated interim review and lessons from SARS-CoV and MERSCoV. International Journal of Infectious Disease 94: 119-124. DOI: https://doi.org/10.1016/j.ijid.2020.03.071.

Xu K, Cai H, Shen Y, Ni Q, Chen Y, Hu S, Li J, Wang H, Yu L, Huang H, Qiu Y, Wei G, Fang Q, Zhou J, Sheng J, Liang T, Li L (2020a) Management of corona virus disease-19 (COVID-19): The Zhejiang experience. Journal of Zhejiang University. Medical Sciences 49(1):147-157. DOI: 10.3785/j.issn.1008-9292.2020.02.02.

Xu Y, Li X, Zhu B, Liang H, Fang C, Gong Y, Guo Q, Sun X, Zhao D, Shen J, Zhang H, Liu H, Xia H, Tang J, Zhang K, Gong S (2020b) Characteristics of pediatric SARS-CoV-2 infection and potential evidence for persistent fecal viral shedding. Nature Medicine 26(4):502-505. DOI: 10.1038/s41591-020-0817-4.

Yang Y, Huang W, Fan Y, Chen GQ (2021) Gastrointestinal microenvironment and the gut-lung axis in the immune responses of severe COVID-19. Frontiers in Molecular Biosciences 8:647508. DOI: 10.3389/fmolb.2021.647508.

Yoo JY, Groer M, Dutra SVO, Sarkar A, McSkimming DI (2020) Gut microbiota and immune system interactions. Microorganisms. 8(10):1587. doi: 10.3390/microorganisms8101587. Erratum in: Microorganisms 8(12): PMID: 33076307; PMCID: PMC7602490.

Yuan C, Wang H, Li K, Tang A, Dai Y, Wu B, Zhang H, Chen J, Liu J, Wu W, Gu S, Wang H, Xu H, Wu M, Yu M, Wang Y, Yu X, He J, Liu S, Zhang Y, Tong Z, Yan J (2021) SARS-CoV-2 viral shedding characteristics and potential evidence for the priority for faecal specimen testing in diagnosis. PLoS One 16(2):e0247367. doi: 10.1371/journal.pone.0247367.

Yusuf F, Fahriani M, Mamada SS, et al. (2021) Global prevalence of prolonged gastrointestinal symptoms in COVID-19 survivors and potential pathogenesis: A systematic review and meta-analysis [version 1; peer review: 2 approved]. F1000Research 10:301 (https://doi.org/10.12688/f1000research.52216.1)

Zang R, Gomez Castro MF, McCune BT, Zeng Q, Rothlauf PW, Sonnek NM, Liu Z, KF, Wang X, Greenberg HB, Diamond MS, Ciorba MA, Whelan SPJ, Ding S (2020) TMPRSS2 and TMPRSS4 promote SARS-CoV-2 infection of human small intestinal enterocytes. Science Immunology 5(47):eabc3582. doi: 10.1126/sciimmunol.abc3582.

Zhang H, Kang Z, Gong H, Xu D, Wang J, Li Z, Li Z, Cui X, Xiao J, Zhan J, Meng T, Zhou W, Liu J, Xu H. (2020) Digestive system 
is a potential route of COVID-19: an analysis of single-cell coexpression pattern of key proteins in viral entry process. Gut 69(6):1010-1018. doi: 10.1136/gutjnl-2020-320953.

Zhang J, Dong W (2020) Expression of B cell translocation gene 1 protein in colon carcinoma and its clinical significance. Recent Patents on Anti-Cancer Drug Discovery 15(1):78-85. doi:10.2174/1574892815666200109113114.

Zhang Y, Cen M, Hu M, Du L, Hu W, Kim JJ, Dai N (2021) Prevalence and persistent shedding of fecal SARS-CoV-2 RNA in patients with COVID-19 infection: A systematic review and metaanalysis. Clinical and Translational Gastroenterology 12(4):e00343. DOI: 10.14309/ctg.0000000000000343.
Zhong P, Xu J, Yang D, Shen Y, Wang L, Feng Y, Du C, Song Y, Wu C, Hu X, Sun Y (2020) COVID-19-associated gastrointestinal and liver injury: clinical features and potential mechanisms. Signal Transduction and Targeted Therapy 5(1):256. DOI: 10.1038/s41392-020-00373-7.

Zuo T, Zhang F, Lui GCY, Yeoh YK, Li AYL, Zhan H, Wan Y, Chung ACK, Cheung CP, Chen N, Lai CKC, Chen Z, Tso EYK, Fung KSC, Chan V, Ling L, Joynt G, Hui DSC, Chan FKL, Chan PKS, Ng SC (2020) Alterations in gut microbiota of patients with COVID-19 during time of hospitalization. Gastroenterology 159(3):944-955.e8. DOI: 10.1053 j.gastro.2020.05.048 